\title{
PT-conditions of deformation within the Palaeoproterozoic South Finland shear zone: some geothermobarometric results
}

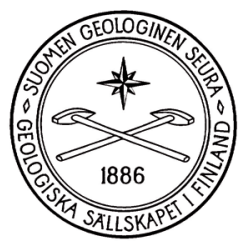

\author{
Taija Torvela ${ }^{1)^{*}}$ and Hans Annersten ${ }^{2)}$ \\ ${ }^{1)}$ Department of Geology and Mineralogy, Abo Akademi University, FI-20500 Turku, Finland \\ ${ }^{2)}$ Department of Earth Sciences, Uppsala University, Villavägen 16, SE-75236 Uppsala, Sweden
}

\begin{abstract}
Four rock samples were collected from the crustal-scale South Finland shear zone in order to compare PT-conditions of deformation between gneissose and mylonitic rock types. Two of the samples were collected from a garnet-bearing gneiss representing an early ductile shearing phase. The two other samples were collected from a 30-meter-wide ultramylonite zone; first sample representing the ultramylonite and the second sample a less deformed amphibole-rich gneiss lens within the zone, interpreted to be the mylonite protolith. The new GBPQ geobarometer and the Gt-Bt exchange geothermometer were applied to the two garnet-bearing samples. The temperature conditions of the ultramylonites and the gneissose protolith were compared with the amphibole-plagioclase thermometer by Holland and Blundy (1994).

The transpressive ductile shearing that produced the granodioritic and tonalitic gneisses within the study area is interpreted to have taken place in conditions with minimum metamorphic peaks at approximately $680^{\circ} \mathrm{C}$ and $7 \mathrm{kbar}$ as indicated by the GBPQ barometer and Gt-Bt thermometer. The results of the Hbl-Plg thermometry, based on the ultramylonite and amphibole gneiss data, suggest that the ultramylonite was formed at minimum $50^{\circ} \mathrm{C}$ lower temperature conditions than the surrounding gneisses (the uncertainty of the $\mathrm{Hbl-Plg}$ thermometer is $35-40^{\circ} \mathrm{C}$ ). This is consistent with field observations of a large-scale reactivation of the shear zone after the main transpressive phase of the late stages of the Svecofennian orogen in Southern Finland.
\end{abstract}

Key words: shear zones, gneisses, ultramylonite, deformation, P-T conditions, Paleoproterozoic, Kökar, Åland Province, Finland

*Corresponding author e-mail: ttorvela@abo.fi 


\section{Introduction}

The Svecofennian crust in southern Fennoscandia was established about $1.8 \mathrm{Ga}$ ago after a prolonged history of accretion and intrusion. In the late stages of this orogen the regional NNW-SSE compression (e.g. Ehlers \& Lindroos, 1990) was partitioned into several transpressional, ductile shear zones throughout the southern Svecofennian domain (e.g. Väisänen, 2002; Sjöström \& Persson, 2001). A major ductile shear zone, "the South Finland shear zone" (SFSZ) can be traced for almost $200 \mathrm{~km}$ in the archipelago off the southern and south-western coast of Finland (Fig. 1 a). The more than a kilometre wide zone shows traces of a long history of activity starting with a wide zone of medium-grained gneisses formed by ductile dextral shearing, locally followed and/or overprinted by mylonites and pseu- dotachylytes. The rocks to the south of the shear zone are dominantly felsic, steeply dipping, ca. 1.88 Ga old gneissose granitoids (mostly granodiorites and tonalites) with local mafic lenses (Ehlers et al., 2004). Within the shear zone, these granitoids become strongly foliated with local lenses of less deformed, folded granodioritic gneisses and mafic, locally brecciated but generally very weakly deformed rocks. The steeply dipping foliation within the shear zone anastomoses around the less deformed lenses but has an overall strike of ca. $120^{\circ}$. The SFSZ is approximately parallel to the contact between gneissose granitoids with W to SW-striking foliations to the south and the structurally overturned, sub-horizontal 1.88 Ga old (regionally migmatised ca. 1.83 Ga ago) supracrustal rocks to the north (e.g. Ehlers et al., 2004). The relationship between the migmatitization and the shearing is not known. a

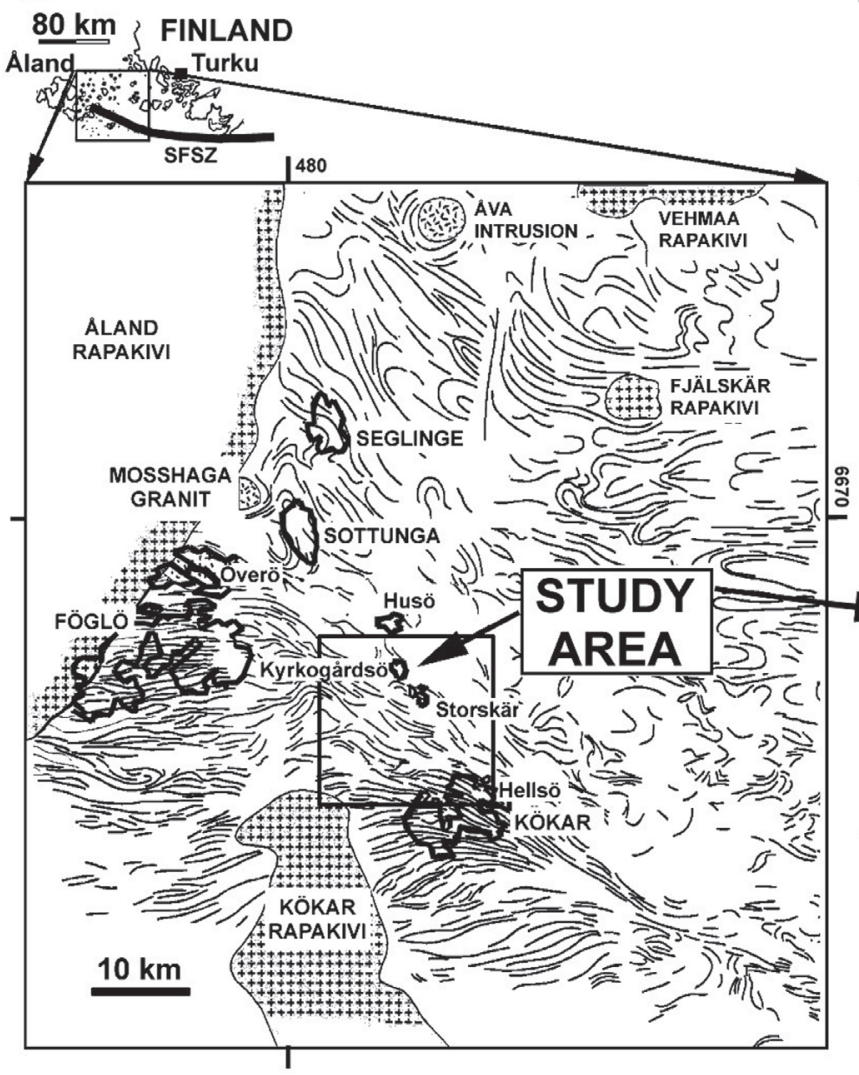

b Samples KY-2/03 (amphibole gneiss) and $\mathrm{KY}-4 / 03$ (ultramylonite)

Fig. I. a) Foliation map of Åland archipelago (modified from Ehlers \& Lindroos 1990). The overall dextral kinematics of the shearing is clearly visible. b) Study area and the sampling locations. 
The maximum age for the earliest ductile shearing is determined by ca. $1885 \mathrm{Ma}$ old zircons in banded granodioritic gneisses (Ehlers et al., 2004). The main ductile deformation phase was essentially over ca. $1.79 \mathrm{Ga}$ ago as defined by U-Pb single zircon ages from weakly deformed granitic dykes that intruded the shear zone during the late phases of the ductile deformation (Ehlers et al., 2004).

The foliation along the margins of the dextral ductile shear zone is folded along roughly E-W trending fold axes plunging eastwards. The lineations within the gneissose foliation of the shear zone plunge gently to steeply eastwards, which combined with the overall dextral kinematics of the shear zone possibly indicates a relative upward movement of the SW side.

In this study we estimated the physical conditions during the formation of two different deformation systems within the SFSZ. Rock samples around Kökar and Kyrkogårdsö islands in the Åland archipelago (Fig. 1) were collected for analysis of selected mineral parageneses. Geothermobarometric methods were applied on the studied rock samples to estimate the metamorphic P-T conditions.

\section{Field relationships, sampling, pe- trography and mineral chemistry}

The rock types within the SFSZ can roughly be divided into three types: the ductilely deformed gneisses (Fig. 2) that belong to the earliest shearing phase; the semi-ductile mylonites (Fig. 3), presumably belonging to a somewhat younger deformation phase; and the brittle pseudotachylytes, representing the last movements along the zone. The pseudotachylytes are not included in this study. The gneisses cover most of the research area, while the mylonites are present as narrow, mostly as $\mathrm{cm}$-scale but occasionally as up to $30-40 \mathrm{~m}$ wide zones, the most striking of which can be found on the island of Kyrkogårdsö (Fig. 1b). The widest mylonite zones commonly follow the strike of the gneissose foliation, while some of the narrow zones also cut the ductile gneisses.

The ductilely deformed gneisses contain zones of differing compositions, easily recognisable in the field.

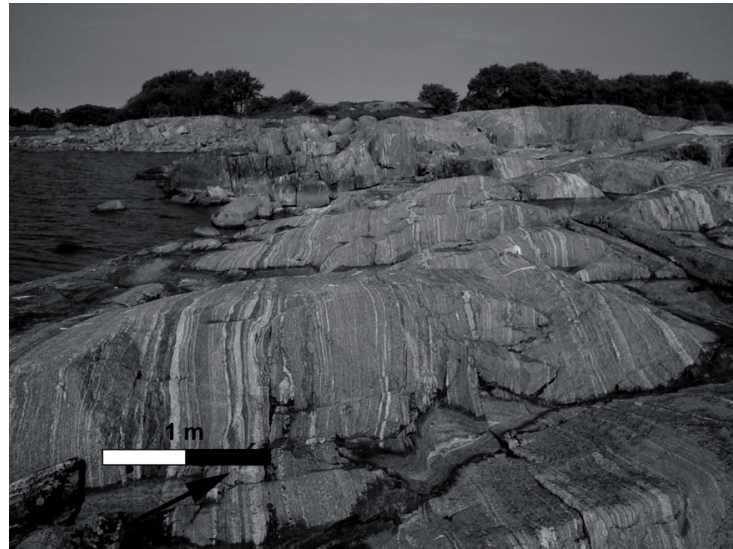

Fig. 2. Medium-grained ductilely sheared granodioritic gneiss. Sommarö, Kyrkogårdsö.

The widths of the zones vary from less than one meter to several tens of metres. The gneisses are here divided into three types: 'alkali feldspar gneisses' with a granitic to granodioritic mineralogy; 'amphibole gneisses' with a tonalitic composition; and mafic lenses that display a less gneissose character, being brecciated or only weakly foliated. The mafic lenses are not further examined within the scope of this study. A typical mineral assemblage in the alkali feldspar gneisses is quartz, plagioclase, potassium feldspar, biotite \pm amphibole with accessory minerals from the epidote group, titanite and apatite. The mineral assemblage in the amphibole gneisses is very similar apart from the alkali feldspar, which is often absent, the hornblende being a dominant mineral instead. The bi-

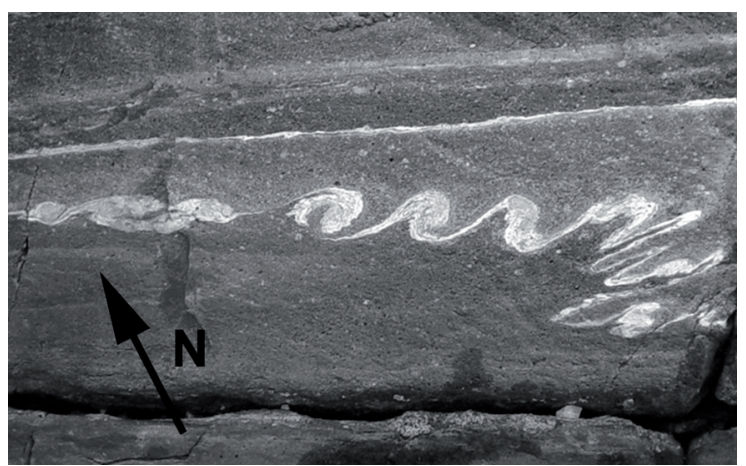

Fig. 3. A detail from a 30-m-wide ultramylonitic zone with dextral sense of shear as shown by the $\delta$-porphyroclasts. Kyrkogårdsö. Width of the photo is $10 \mathrm{~cm}$. 
otites in most gneiss types are typically dark greenish brown and the hornblendes are of the dark brownish green to dark green variety.

The gneisses have very low aluminium contents. As a result, aluminous minerals such as staurolite or aluminium silicates were not found. Garnets are extremely rare in all rock types and only few narrow garnet-bearing layers of granodioritic gneiss along the gneissose foliation have been identified, mostly on Hellsö, northern part of the island of Kökar close to the southern border of the shear zone (Fig. 1 b). These garnets occasionally show some retrograde alteration to biotite and chlorite as indicated by narrow reaction rims around and within the fractures of the garnets. However, even unaltered garnets were common in some parts of the garnet-bearing zone. In contrast to the other gneiss types, the biotite in the garnetbearing gneisses is commonly red-brown in colour indicating a high Ti-content. Epidote, hornblende and titanite are largely absent. Instead, occasional white mica is present as very small grains.

Some retrograde reactions normally observed in metabasic rocks have been identified in some of the amphibole-rich tonalitic gneisses. The most typical reaction that was observed is (from high to low grade, not balanced):

$$
\mathrm{Hbl}+\mathrm{Plg}+\mathrm{Qtz}=\mathrm{Ep}+\mathrm{Ab}+\mathrm{Chl}
$$

This reaction takes place at ca. $500^{\circ} \mathrm{C}$ at 4 kbar (Liou et al., 1974) with a successive enrichment of the albite component in the plagioclase and decreasing $\mathrm{Na}$ and $\mathrm{Al} / \mathrm{Si}$ ratio in the hornblende with lowering temperature.

The mylonites were derived from the coarser gneissose rocks, and have rounded porphyroclasts of plagioclase and alkali feldspar or amphibole. The retrograde reactions are, however, more intense in the mylonites resulting in abundant small epidote grains in the fine-grained biotite-rich matrix. The porphyroclasts however are largely unaffected by the matrix retrogression.

Four samples were selected for analysis. Two of the samples (K-5/02 and K-3/03) were collected from the medium-grained, garnet-bearing ductile gneisses in Hellsö, northern Kökar (Fig. 1b). Sample K$5 / 02$ consists of plagioclase, quartz, red-brown biotite with minor local chloritization and garnet with accessory zircon and opaques. The texture is that of a recovered rock with relatively straight grain boundaries and lack of undulose extinction, implying that the temperature remained relatively high after the peak of the deformation so that static recrystallisation processes were enabled (Passchier \& Trouw 1998). This in turn implies that geochemical equilibrium may have been reached. The garnets in the sample are porphyroblasts, pre- to syn-tectonic with irregular inclusion patterns, grown over the earlier prograde mineral assemblages during metamorphism. The foliation defined by the orientated biotite grains is deflected around the porphyroblasts. In sample K-5/02 the garnets are Fe-rich with minor amounts of $\mathrm{Ca}, \mathrm{Mn}$ and $\mathrm{Mg}$ (Table 1). Microprobe analyses show the garnets to be relatively homogeneous, although there are some occasional variations in geochemistry and local impurities of feldspar and mica within the grains. Some retrograde manganese zoning at the rims can be observed. The more homogeneous part of the garnet core is therefore interpreted to represent the peak metamorphism conditions (Fig. 4a). The plagioclase cores in sample K-5/02 are constantly more $\mathrm{Na}$-rich and Ca-poor than the grain rims (Table 1). This implies that since the rocks are poor in $\mathrm{Ca}$, the albitic component in plagioclase has increased during garnet growth, i.e. during progressive metamorphism (Spear, 1993), while the rims richer in Ca were formed during retrograde metamorphism. The grain cores have thus not been thoroughly equilibrated to retrograde conditions. The plagioclase cores in this sample have therefore been interpreted to represent the minimum peak metamorphic conditions of deformation.

The mineralogy of the sample $\mathrm{K}-3 / 03$ is rather similar to the sample K-5/02. However, the sample K3/03 has experienced a more extensive retrograde alteration. Plagioclase in this sample is thoroughly sericitised, sometimes with a partial rim of muscovite as a retrograde phase, and the cores show a Ca-content equal to or in some cases even higher than the grain 
a)

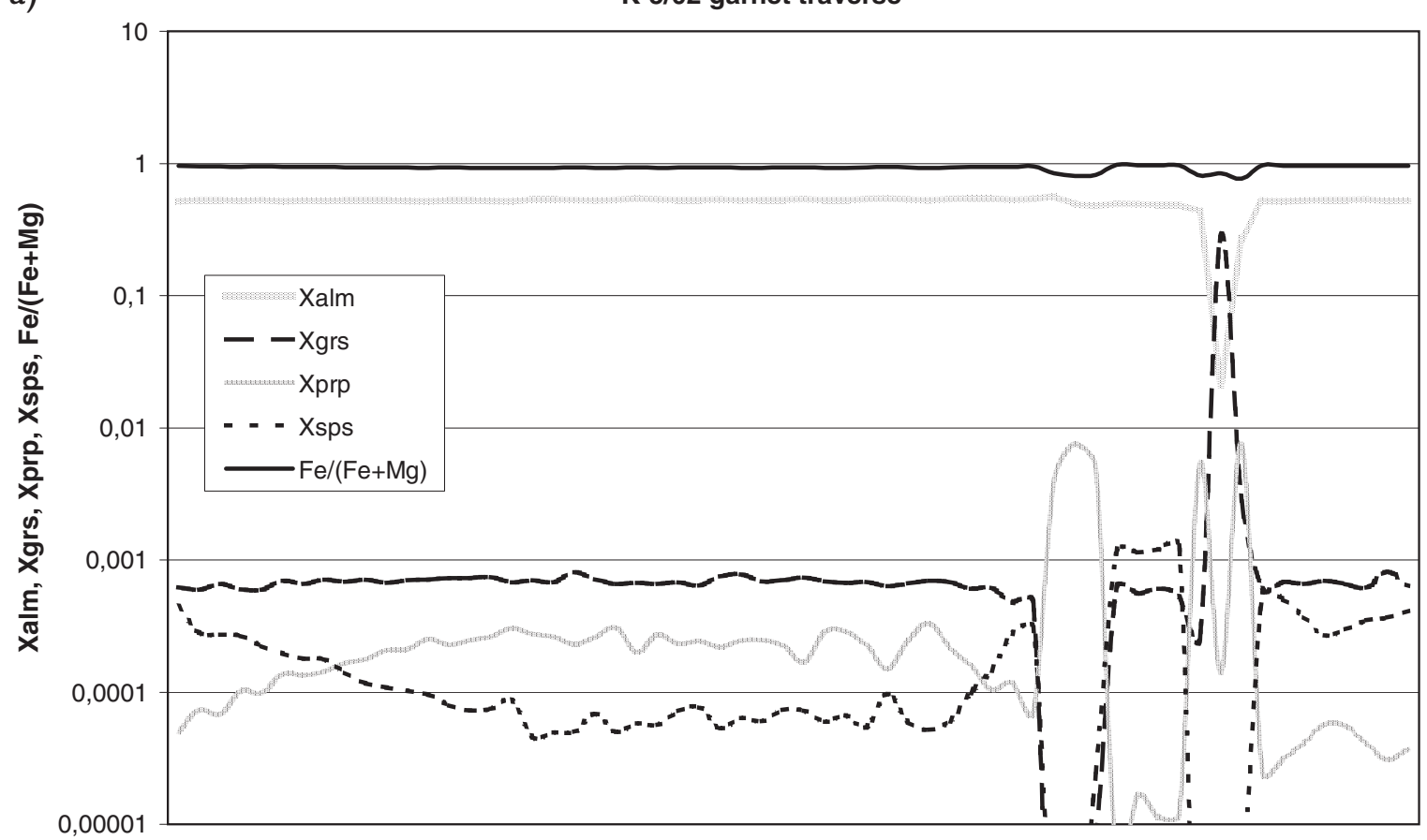

Length of traverse $0.5 \mathrm{~mm}$

b)

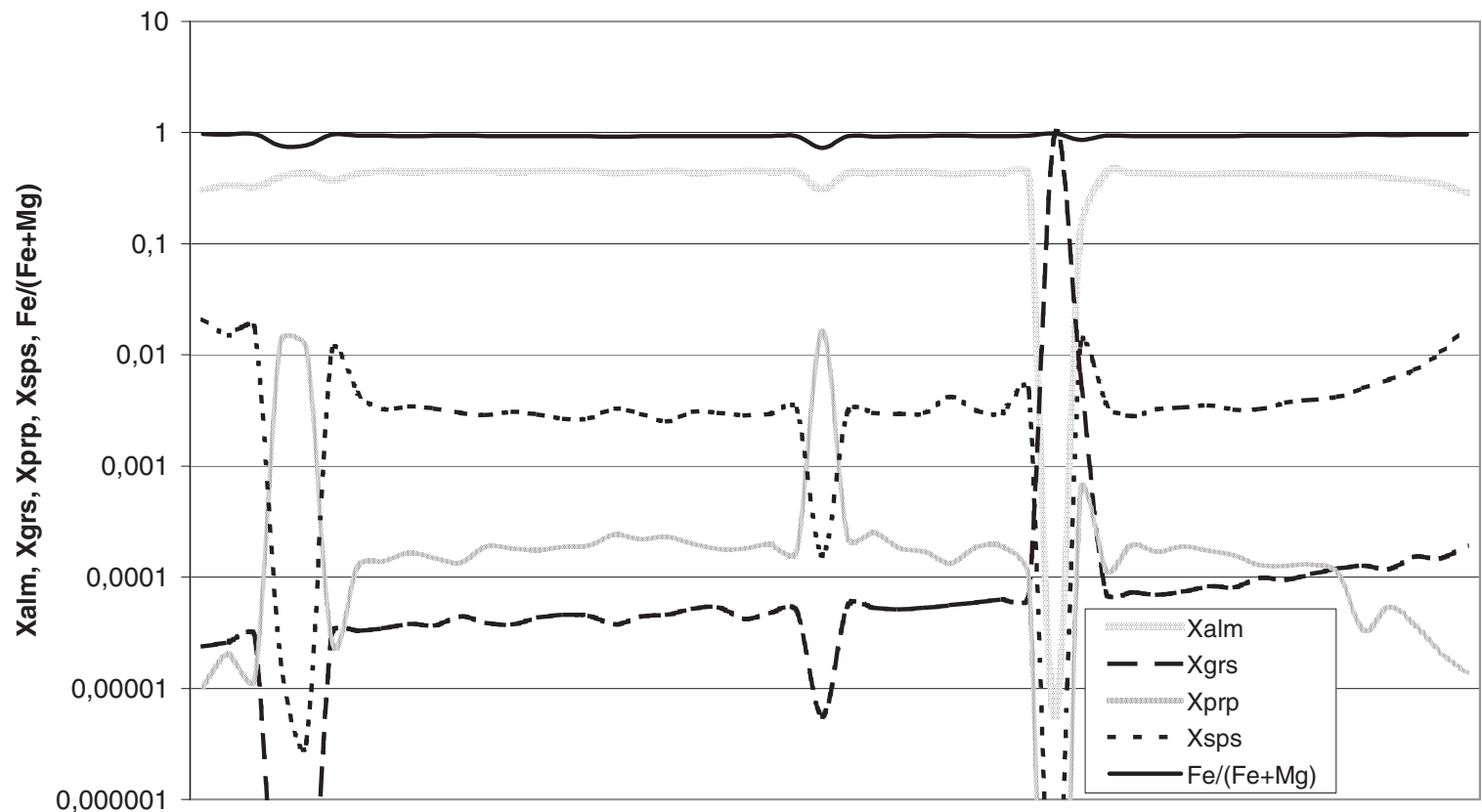

Length of traverse $0.8 \mathrm{~mm}$

Fig. 4. The compositional variations in garnets from the two analysed garnet-bearing gneiss samples. $X=$ activity of the end-members. a) Sample K-5/02. 6, b) Sample K-3/03. The profiles in both garnets are typical for high-grade garnets with some retrograde effects along grain margins. 


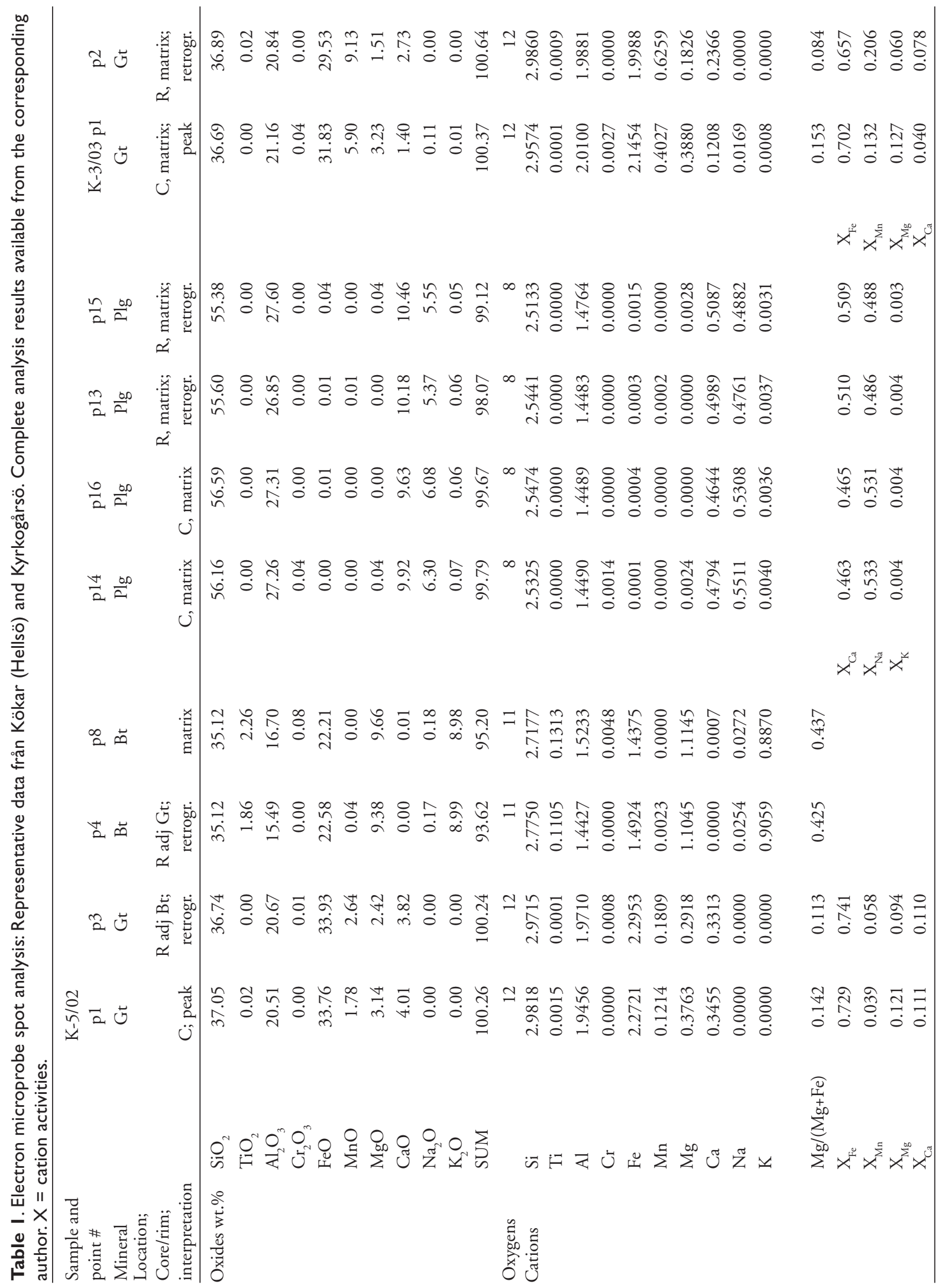




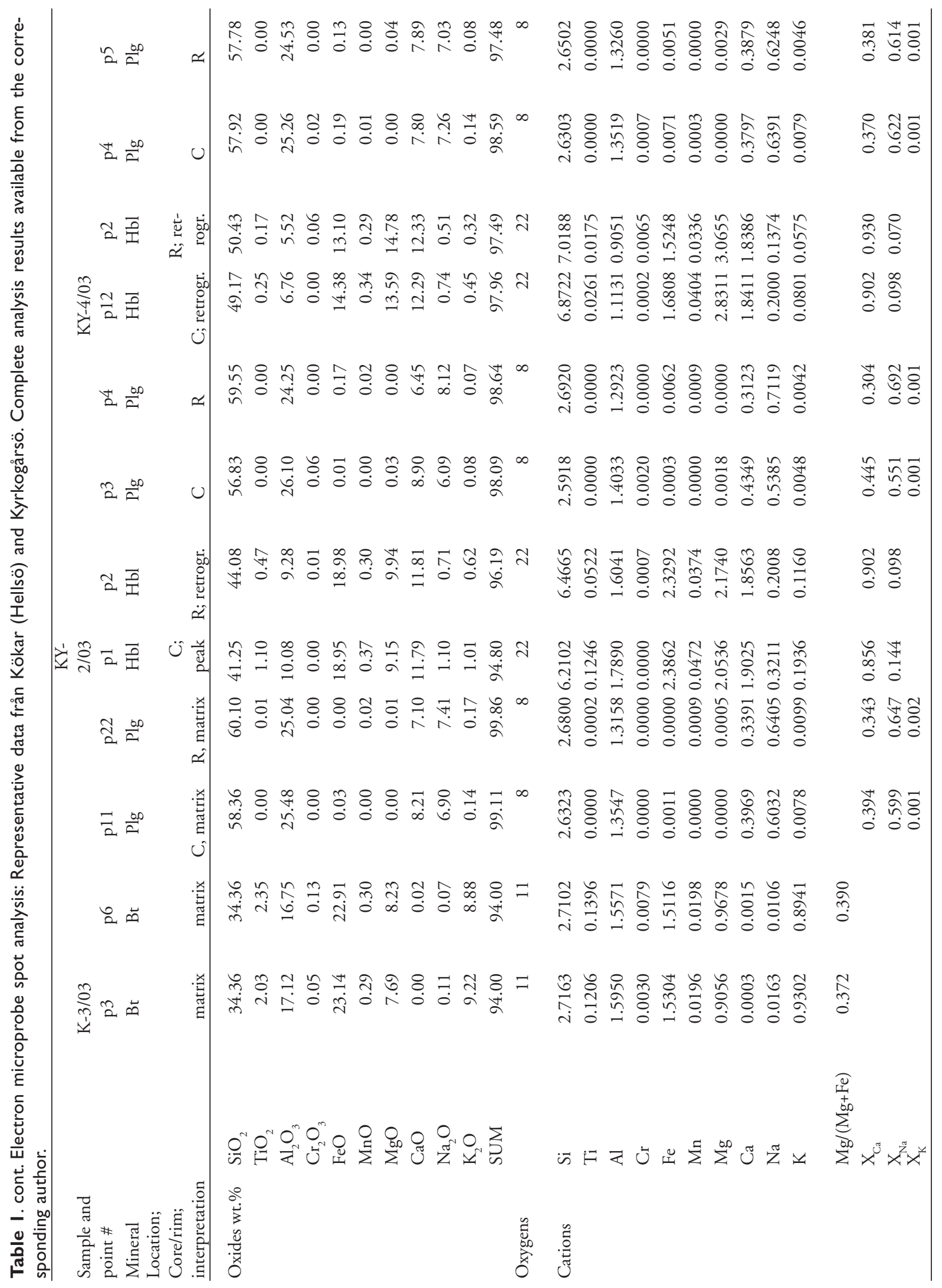


rims. The plagioclase has therefore not maintained its peak metamorphic composition. Also the biotite is slightly more retrogressed to chlorite than in sample $\mathrm{K}-5 / 02$. The garnets in this sample are slightly poorer in $\mathrm{Fe}$ and $\mathrm{Ca}$ being instead richer in $\mathrm{Mn}$ than the garnets in the sample K-5/02. The garnets frequently show minor chlorite alteration along the grain rims and cracks. The garnet traverse analyses show minor retrograde Mn-alteration, localised along the porphyroblast rims (Fig. 4 b). Even this sample has preserved the static recrystallisation textures formed at high temperatures.

The two other samples were collected from a ca. $30 \mathrm{~m}$ wide, intensely sheared zone on the island of Kyrkogårdsö (Fig. 1 b). The zone is dominated by mylonites and ultramylonites with streaks of less mylonitized, medium-grained material. Sample KY-2/03 is from an intensely sheared, medium-grained amphibole gneiss of a tonalitic composition, while sample KY-4/03 represents an amphibole-bearing ultramylonite located within a few metres from the amphibole gneiss. The amphibole is hornblende with minor $\mathrm{Na}$ (Table 1). The hornblendes in both samples show minor zoning, the grain cores showing slightly higher contents of $\mathrm{Al}, \mathrm{Na}$ and $\mathrm{Ti}$ than the grain rims, the cores instead being somewhat depleted in $\mathrm{Si}$ and $\mathrm{Mg}$. The plagioclase in the gneissose sample also shows some zoning (Table 1 ).

The gneissose sample (KY-2/03) consists of hornblende, plagioclase, biotite and quartz with accessory titanite, zircon and opaques. Some very fine-grained chlorite has formed within thin shear bands eveident in thin sections. The core of the plagioclase is more Ca-rich than the rim. The quartz frequently forms small subgrains with irregular boundaries and displays some undulose extinction, suggesting that the deformation continued at least some time after the metamorphic peak. Also the plagioclase is frequently undulose, although it generally forms larger grains than the quartz. The mineralogy and the petrography of the gneissose sample suggest that the retrograde alteration ceased in relatively high-grade conditions. This implies, since no lower-grade retrograde assemblages have developed, that: i) the temperature decreased relatively rapidly after the conditions recorded in the rock, or ii) the rock had become too depleted of volatiles to allow further hydration and during retrogression. The compositions of grain rims in this sample were interpreted to represent the approximate metamorphic temperature conditions, while the core compositions possibly indicate the minimum conditions during the magmatic crystallization of the rock.

The mineralogy of the matrix of the mylonitic sample KY-4/03 is a typical greenschist facies assemblage with very fine-grained plagioclase, biotite, chlorite, epidote and calcite. Porphyroclasts of plagioclase, hornblende and small titanite have been preserved in the extremely deformed matrix. It is unclear whether the alternation is a syn- or post-mylonitization feature. The majority of the retrogressive greenschist facies alteration is concentrated to the matrix. The minor geochemical zoning present in the amphibole porphyroclasts is the last preserved record of the changing metamorphic conditions prior to the mylonitization. Mylonites were probably formed in lower conditions than recorded by the porphyroclast rims since the original grain rims can be expected to have been destroyed during the mylonitic shearing. Therefore, the composition of the rims in the mylonite sample are considered to represent the maximum mylonitization conditions.

The main petrographic and mineralogical features of the samples that were analysed during this study are summarised in Table 2.

\section{Thermobarometry method de- scription}

Polished thin sections were prepared from the four rock samples collected from the zone of the most intensive shearing (Fig 1b, Table 2). The samples were analysed at the electron microprobe laboratory at the Department of Earth Sciences at Uppsala University. The laboratory uses a Cameca SX-50 equipped with three wavelength dispersive spectrometers and a backscattered electron detector.

The mineral assemblages present in the samples restricted the application of many geothermobaromet- 


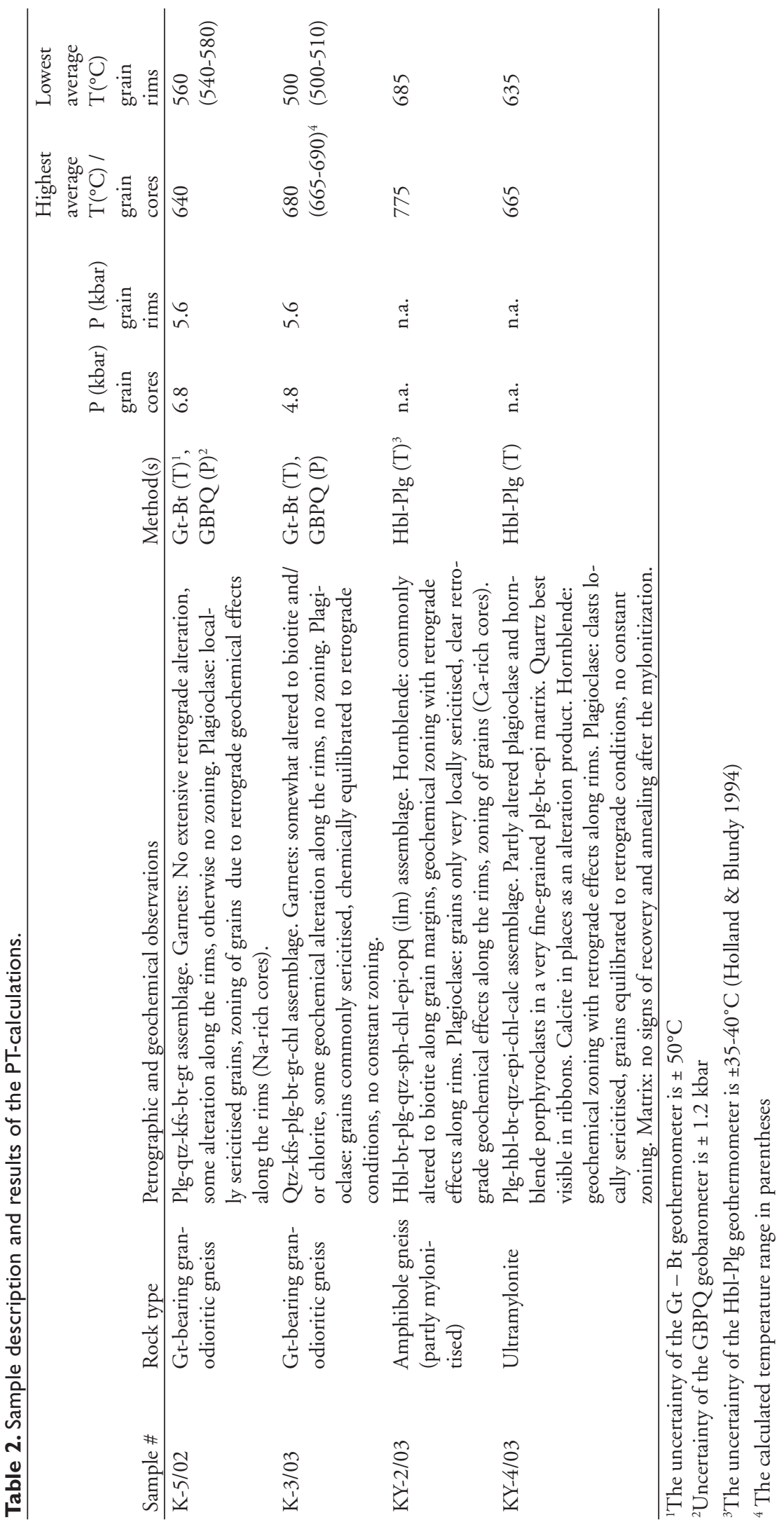


ric methods. The recently calibrated garnet-biotiteplagioclase-quartz (GBPQ) geobarometer (Wu et al., 2004) could be applied with some certainty, but due to the rarity of garnet-bearing rocks within the study area the number of suitable samples was very small. The garnet-biotite Fe-Mg exchange geothermometer was combined with the GBPQ geobarometer. An attempt to determine the temperature conditions of the mylonitic deformation in comparison to that of the gneissose deformation with the amphibole-plagioclase thermometer was also made.

The amphibole-plagioclase thermometer was calibrated by Holland \& Blundy (1994) based on the equilibria

1. $\mathrm{Ed}+4 \mathrm{Qtz}=\mathrm{Tr}+\mathrm{Ab}$ (the edenite-tremolite thermometer)

2. $\mathrm{Ed}+\mathrm{Ab}=\mathrm{Ri}+\mathrm{An}$ (the edenite-richterite thermometer)

The edenite-tremolite thermometer requires silica saturated parageneses although the edenite-richterite thermometer has successfully been applied also to silica-saturated systems. The presence of free quartz in all four analysed samples indicates that the rocks were formed in a silica-saturated environment. The two thermometers should therefore give approximately similar results when applied to a single set of analytical data. The uncertainty of the Hbl-Plg thermometer is $\pm 35-40^{\circ} \mathrm{C}$ (Holland \& Blundy, 1994).

The $\mathrm{Mg}$-Fe exchange geothermometers are widely used. The most popular Mg-Fe exchange thermometer is based on the reaction between garnet and biotite (not balanced):

$$
\begin{aligned}
& \mathrm{Fe}_{3} \mathrm{Al}_{2} \mathrm{Si}_{3} \mathrm{O}_{12}+\mathrm{KMg}_{3} \mathrm{AlSi}_{3} \mathrm{O}_{10}(\mathrm{OH})_{2}=\mathrm{Mg}_{3} \mathrm{Al}_{2} \mathrm{Si}_{3} \mathrm{O}_{12} \\
+ & \mathrm{KFe}_{3} \mathrm{AlSi}_{3} \mathrm{O}_{10}(\mathrm{OH})_{2} \\
& \text { (almandine }+ \text { phlogopite = pyrope }+ \text { annite })
\end{aligned}
$$

Numerous calibrations have been presented for the Gt-Bt exchange thermometer. Within this study, the calibration of Bhattacharya et al. (1992) was used because of the relatively low uncertainty of the calibration $\left( \pm 50^{\circ} \mathrm{C}\right)$.
The GBPQ barometer, like many geobarometers, is based on net transfer reaction since such reactions often result in large volume changes. The GBPQ net transfer equilibrium reactions from higher to lower pressure are:

$$
\begin{aligned}
& \mathrm{Mg}_{3} \mathrm{Al}_{2} \mathrm{Si}_{3} \mathrm{O}_{12}+2 \mathrm{Ca}_{3} \mathrm{Al}_{2} \mathrm{Si}_{3} \mathrm{O}_{12}+3 \mathrm{~K}\left(\mathrm{Mg}_{2} \mathrm{Al}\right) \\
& \left(\mathrm{Si}_{2} \mathrm{Al}_{2}\right) \mathrm{O}_{10}(\mathrm{OH})_{2}+6 \mathrm{SiO}_{2}=6 \mathrm{CaAl}_{2} \mathrm{Si}_{2} \mathrm{O}_{8}+ \\
& 3 \mathrm{KMg}_{3}\left(\mathrm{AlSi}_{3} \mathrm{O}_{10}(\mathrm{OH})_{2}\right. \\
& \quad \text { (pyrope + grossular + eastonite + quartz = anorth- } \\
& \text { ite + phlogopite) }
\end{aligned}
$$

and

$\mathrm{Fe}_{3} \mathrm{Al}_{2} \mathrm{Si}_{3} \mathrm{O}_{12}+2 \mathrm{Ca}_{3} \mathrm{Al}_{2} \mathrm{Si}_{3} \mathrm{O}_{12}+3 \mathrm{~K}\left(\mathrm{Fe}_{2} \mathrm{Al}\right)$ $\left(\mathrm{Si}_{2} \mathrm{Al}_{2}\right) \mathrm{O}_{10}(\mathrm{OH})_{2}+6 \mathrm{SiO}_{2}=6 \mathrm{CaAl}_{2} \mathrm{Si}_{2} \mathrm{O}_{8}+$ $3 \mathrm{KFe}_{3}\left(\mathrm{AlSi}_{3}\right) \mathrm{O}_{10}(\mathrm{OH})_{2}$

(almandine + grossular + siderophyllite + quartz $=$ anorthite + annite)

The barometer is calibrated to pelitic compositions when the activities of the relevant end-members are $\mathrm{X}_{\text {Gros }}>3 \%, \mathrm{X}_{\mathrm{An}}>17 \%$ and $\mathrm{X}_{\mathrm{Al}}$ in biotite $>3 \%$ (Wu et al., 2004). If these conditions are not met the barometer should be applied with caution. In sample $\mathrm{K}-5 / 02$ these conditions are met except for the $\mathrm{X}_{\text {Gros' }}$, which gives cause for some uncertainty regarding the calculations. In sample $\mathrm{K}-3 / 03$ the Ca-content was too low to allow the requirements for grossular and anorthite activities to be met. This leads to significant uncertainties, which together with the extensive retrograde alteration of the sample are reflected in the results (Fig. 5b). The uncertainty of the GBPQ geobarometer when applied to rocks with sufficient mineral activities is $\pm 1.2 \mathrm{kbar}$ (Wu et al., 2004). The error caused by the assumption that the volume during deformation remained constant cannot be estimated, since the amount of fluids released from the rock during deformation is unknown.

\section{Results and interpretations}

The summary of the results of the calculations is presented in Table 2. 
a)
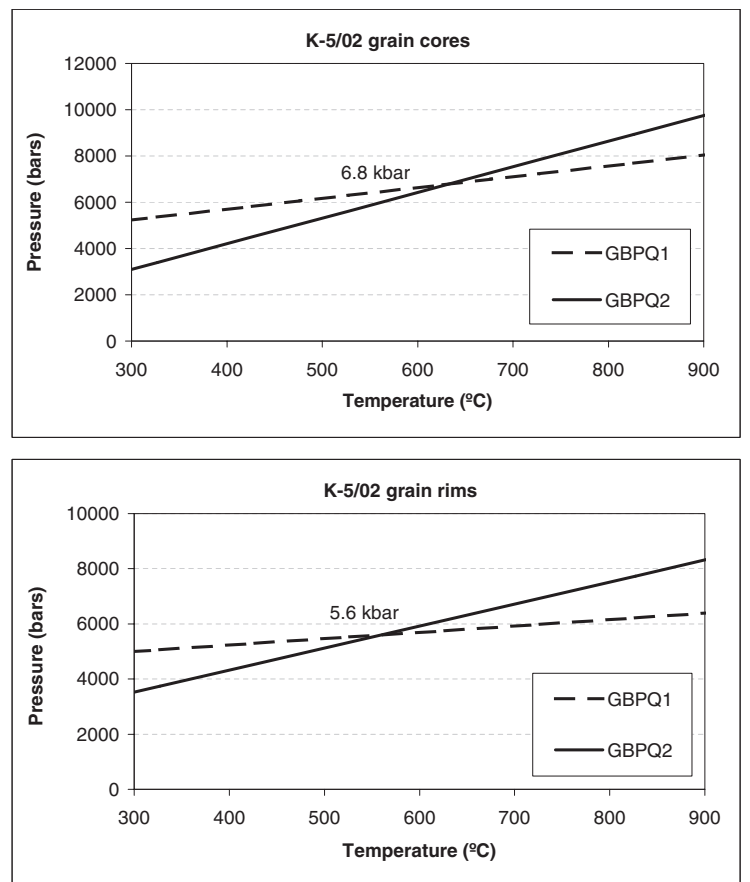

b)
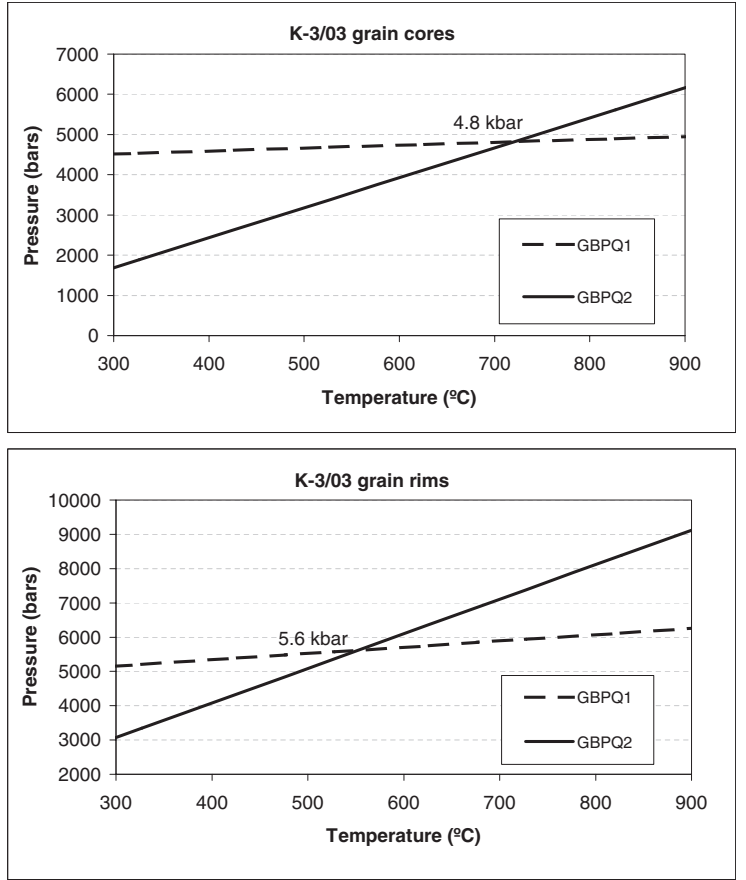

Fig. 5. Graphic presentation of the results of the GBPQ geobarometry applied to the garnet-bearing gneisses from Hellsö, Kökar. a) Sample K-5/02 gives a pressure of 6.8 kbars (6787 bars) calculated from grain core compositions, while the grain rims are indicative of a retrograde pressure of 5.6 kbar (5599 bars). b) Sample K-3/03 has been extensively altered during retrogression: the grain cores give a lower pressure of $4.8 \mathrm{kbar}$, while the core rims record a pressure of $5.6 \mathrm{kbar}$.

The obtained Gt-Bt temperature from the garnet and biotite grain cores in the gneiss samples varied from $640^{\circ} \mathrm{C}$ in the sample $\mathrm{K}-5 / 02$ to $680^{\circ} \mathrm{C}$ in the sample K-3/03. These temperatures can be considered equal within the uncertainty of the method, and it is interesting that the sample K-3/03 that was considered to show more intense retrogressive alteration gives an approximately equal temperature to the less altered sample K-5/02. The calculated temperatures are therefore regarded to reflect the minimum metamorphic peak conditions. The grain rims record significantly lower, retrogressive temperatures of $560^{\circ} \mathrm{C}$ and $500^{\circ} \mathrm{C}$. Not unexpectedly, the more retrogressively altered sample K-2/03 gives lower rim temperatures than sample K-5/02.

The calculations of average grain core compositions in sample K-5/02 (garnet-bearing gneiss) indicate a pressure of $6.8 \mathrm{kbar}$ (Fig. 5a). This is interpreted to represent the approximate peak pressure during deformation that produced the shear zone. The grain rims record a lower pressure of 5.6 kbar, interpreted to be a retrograde pressure. The results from sample K-3/03 can be ignored due to the extensive retrograde alteration and the severe deviation from the mineral activity limits recommended for the GBPQ geobarometer.

The sheared amphibole gneiss (sample KY-2/03) gives core temperatures of approximately $775^{\circ} \mathrm{C}$, while the rim temperatures are clearly lower with $685^{\circ} \mathrm{C}$ (Fig. 6a). The core temperature possibly records the cooling path of the magmatic intrusion. The rim temperature is in a good agreement with the temperatures in the garnet-bearing gneisses and is here suggested to be the minimum temperature of the ductile shearing of the amphibole gneiss. In the ultramylonite sample (KY-4/03), the hornblendes and plagioclases are slightly zoned, still giving core and rim temperatures close to each other $\left(665^{\circ} \mathrm{C}\right.$ and $635^{\circ} \mathrm{C}$, respectively; Fig. $6 \mathrm{~b}$ ). The porphyroclasts seem to have undergone little retrograde equilibration, although the mylonite 
a)

KY-2/03 (gneiss) average temperatures

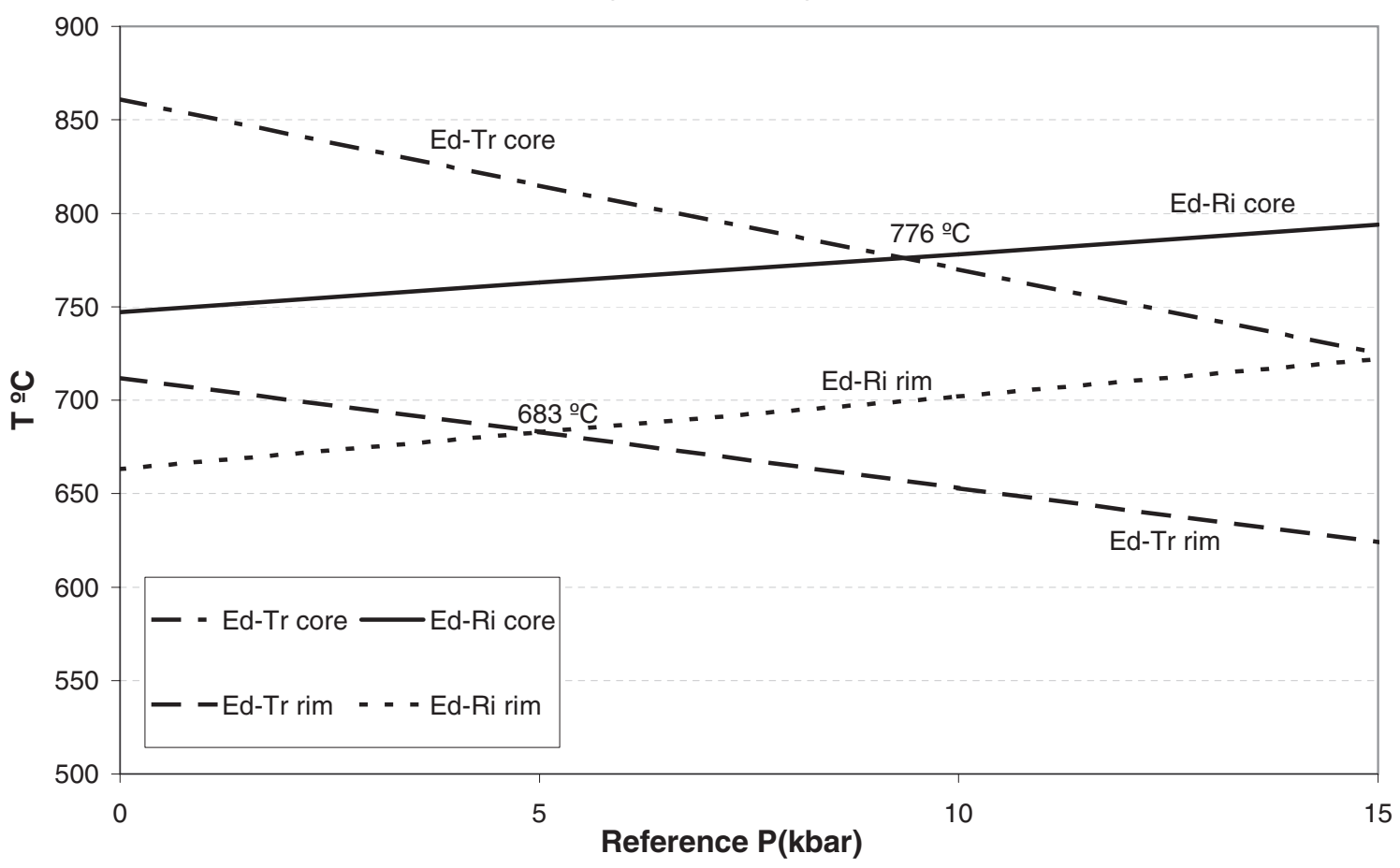

b)

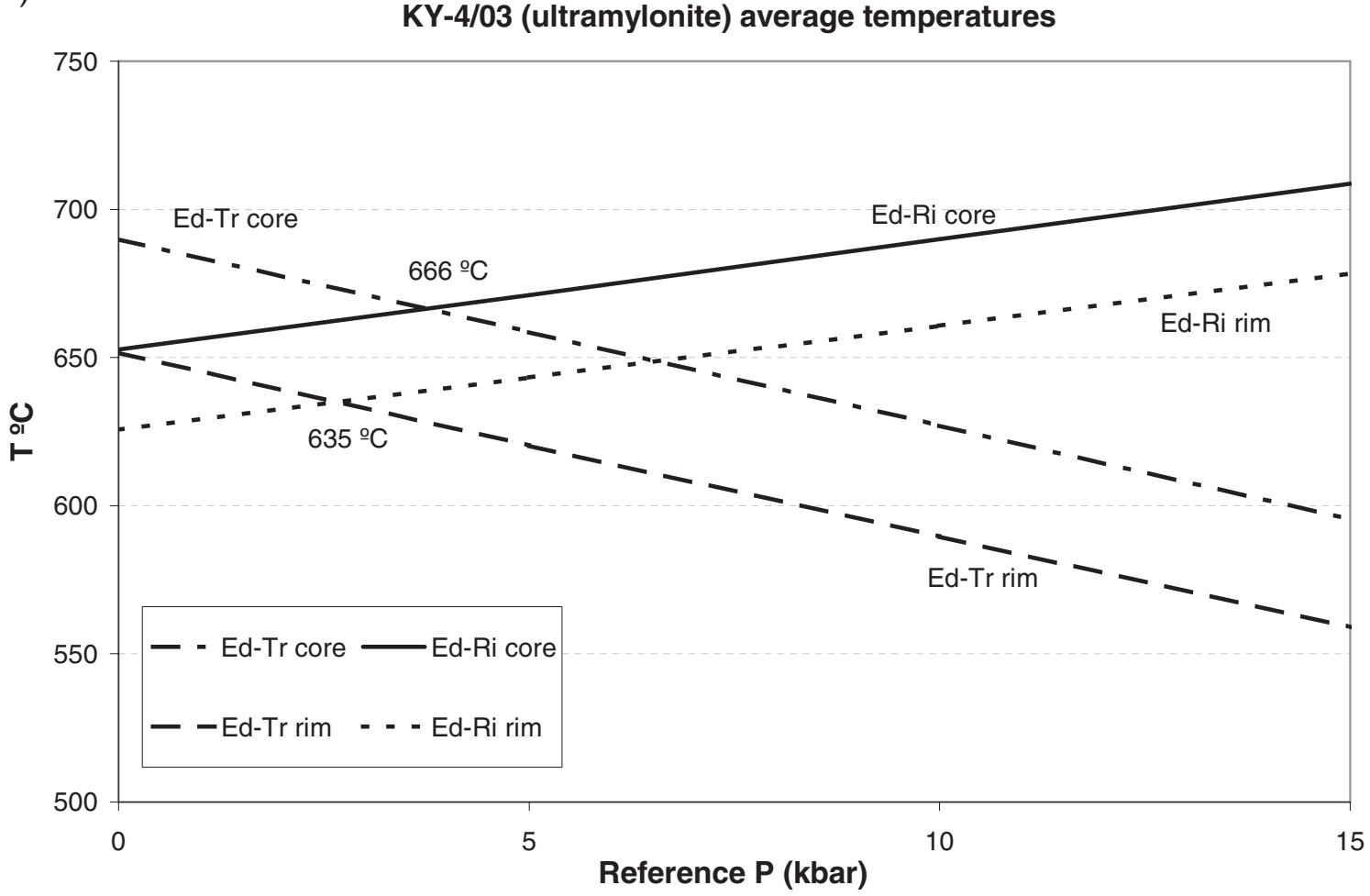

Fig. 6. Results of the Hbl-Plg geothermometric calculations. a) Sample KY-2/03, the mylonite protolith, b) Sample KY-4/03, the ultramylonite. 
matrix contains greenschist facies mineral assemblages. Thus, the temperature seems to have dropped relatively rapidly after the conditions recorded by the porphyroclasts rims. Furthermore, the temperature was not sufficiently high after the mylonitization to allow any annealing of the mylonitised fabric around the clasts. The rim temperature of the clasts is therefore here interpreted as the maximum mylonitization temperature, the actual conditions probably being lower than those recorded by the porphyroclast rims. The analysed mylonite was therefore apparently not formed in relatively high-grade conditions as a result of strain softening and/or strain partitioning during an overall ductile deformation, a possibility suggested by some authors (e.g. Passchier \& Trouw, 1998).

Although the Hbl-Plg method is somewhat pressure-dependent and pressures are used as reference when performing the calculations, the use of the intersection of the two thermometers (Fig. 6) as a pressure indicator should be avoided (Holland \& Blundy, 1994).

\section{Conclusions}

The temperature and pressure calculations based on the mineral compositions in the garnet-bearing gneisses and the amphibole gneiss sample gave results that are somewhat difficult to interpret. However, based on the chemical core-rim relationships within individual grains and the petrographic observations described above, the transpressive ductile shearing of the granodioritic and tonalitic gneisses within the study area is here interpreted to have taken place at minimum metamorphic peak conditions of approximately 640 $680^{\circ} \mathrm{C}$ and $6.8 \mathrm{kbar}$. The obtained pressure should be taken with some caution due to the restrictions described above. Assuming that the calculated pressure is approximately correct, it is higher than usually reported from areas north of the shear zone at similar temperatures. Väisänen \& Hölttä (1999), for example, calculated temperatures and pressures of migmatitization for different locations in the Turku area to be ca. 600 $720^{\circ} \mathrm{C}$ and 3.2-4.7 kbar. Metamorphism at higher pressures of up to 6.3-6.7 kbar was also observed, the associated temperatures, however, being significantly higher (up to $800-825^{\circ} \mathrm{C}$ ), than in this study. The higher pressure indication obtained from the SFSZ possibly reflects the overall kinematics of the shear zone with a relative vertical movement of the southside up, resulting in deeper crustal levels being exposed south of the shear zone. Another possible explanation is a thickening of the crust in the area of the present SFSZ at late stages of the Svecofennian orogeny.

The results of the temperature calculations based on the ultramylonite and the mylonite protolith $\mathrm{Hbl}-$ $\mathrm{Plg}$ data suggest that the ultramylonite was formed at lower metamorphic conditions than the gneisses in the same high-strain zone. The rim temperatures in the amphibole gneiss, interpreted to represent the gneissose shearing, were calculated to $685^{\circ} \mathrm{C}$, while the rim temperatures obtained from the ultramylonite and thought to represent the maximum conditions of the mylonitic deformation were around $635^{\circ} \mathrm{C}$. Lack of pronounced retrograde zoning of the mylonite parageneses could indicate a rapid cooling as a result of the high rate of the late orogenic uplift. The actual mylonitization temperature was lower than what is recorded by the prevailing porphyroclasts. The data gives the first indication that the extensive mylonitization took place later than the ductile shearing. In regional scale it could therefore be argued that the South Finland Shear Zone was repeatedly reactivated along certain zones of weakness, producing streaks where gneissose and mylonitic materials displaying parallel foliation coexist. The wide mylonite zone of Kyrkogårdsö would thus have been produced in more brittle crustal conditions due to reactivation of at least parts of the main shear zone during uplift and exhumation of the rocks, rather than by local strain softening and/or strain partitioning during the ductile shearing phase.

\section{Acknowledgements}

The authors wish to thank Stefan Bergman and Pentti Hölttä for their advice and Sören Fröjdö for his valuable help concerning the PT-calculations. The project received funding from the Finnish Academy of Science and Letters (Vilho, Yrjö and Kalle Väisälä fund), Finn- 
ish Graduate School in Geology and Åbo Akademis Jubileumsfond 1968 .

\section{References}

Bhattacharya, A., Raith, M., Langen, R. \& Sen, S.K., 1992. Non-ideal mixing in the phlogopite-annite binary: Constraints from experimental data on $\mathrm{Mg}$-Fe partitioning and a reformulation of the biotite-garnet geothermometer. Contributions to Mineralogy and Petrology 111, 87-93.

Ehlers, C. \& Lindroos, A., 1990. Low-angle ductile shears in the early Proterozoic rocks of SW Finland. Geologiska Föreningens Förhandlingar 112, 177-178.

Ehlers, C., Skiöld, T. \& Vaasjoki, M., 2004. Timing of Svecofennian crustal growth and collisional tectonics in Åland, SW Finland. Bulletin of the Geological Society of Finland 76, 63-91.

Holland, T. \& Blundy, J., 1994. Non-ideal interactions in calcic amphiboles and their bearing on amphibole-plagioclase thermometry. Contributions to Mineralogy and Petrology 116, 433-447.

Liou, J.G., Kuniyoshi, S. \& Ito, K., 1974. Experimental studies on the phase relations between greenschist and amphibolite in basaltic system. American Journal of Science 274, 613-632.

Passchier, C.W. \& Trouw, R.A.J., 1998. Microtectonics. Springer, $289 \mathrm{p}$.

Sjöström, H. \& Persson, K., 2001. Deformation zones in eastern Bergslagen (Uppland-Sörmland). Uppsala University, Department of Earth Sciences. Research report, $80 \mathrm{p}$.

Spear, F.S., 1993. Metamorphic Phase Equilibria and Pressure-Temperature-Time Paths. Mineralogical Society of America, 799 p.

Väisänen, M., 2002. Tectonic Evolution of the Palaeoproterozoic Svecofennian Orogen in Southwestern Finland. Annales Universitatis Turkuensis, A II, 154, 143 p.

Väisänen, M. \& Hölttä, P., 1999. Structural and metamorphic evolution of the Turku migmatite complex, southwestern Finland. Bulletin of the Geological Society of Finland 71, 177-218.

Wu, C.-M., Zhang, J. \& Ren, L.-D., 2004. Empirical Garnet-Biotite-Plagioclase-Quartz (GBPQ) Geobarometry in Medium- to High-Grade Metapelites. Journal of Petrology 45, 1907-1921. 